\title{
83. Discovery of Pseudomphyma in the Limestone of Erh-tao-kou near Kiturin, Mansyü*).
}

\author{
By Hisakatsu YABE and Motoki EGUCHI. \\ (Comm. by H. YABE, M.I.A., June 12, 1944.)
}

In the December number, 1943, of these proceedings ${ }^{1)}$, attention was given to the occurrence of a coral faunule, decidedly older than the Lower Carboniferous, in a limestone of the Kiturin formation, exposed at Erh-tao-kou ${ }^{2}, 15 \mathrm{~km}$ west of Kiturin ${ }^{3)}$, Mansyû. The limestone seems to be rich in fossil corals, but since the material we then had at our disposal was rather scanty, only four forms could be distinguished, namely: "Favosites, sp. nov., cf. Striatopora cristata (Blumenbach), Cladopora? sp., and Aulopora? sp. Except the coral assigned to the genus Favosites, none was specifically, or strictly speaking even generically, determinable; nevertheless, we believed the coral assemblage to bear some vestiges of Devonian coral faunas. This view has since then been found to be incorrect for it does not apply to the coral of extraordinary interest recently discovered by Mr. K. T. Li of Kiturin in the limestone.

The new material kindly offered us by the collector for study consists of several specimens, evidently of one and the same species belonging to the Tetracoralla, which, though more or less deformed, have been preserved in a condition good enough for detailed microscopical examinations of the internal structure of the corallum. The description follows :

Pseudomphyma infundibula, sp. nov.

Figs. 1-6.

Corallum simple, tall, funnel-shaped, consisting of long, slender, straight, stalk-like posterior part, which is horizontally tabulated within, and the very wide, horizontally expanded upper, calicinal part. Stalklike part almost cylindrical in its posterior half and conical in the rest, bearing a few scars evidently of radiciform processes on the outside; upward gradually passing into the basal part of the calice, which is wide, horizontally expanded, cup-shaped and hollow, with broad reflexed periphery. Surface with numerous, slightly raised acretion striae, and numerous impressed lines running along the whole length of the corallum. Theca thin, thickened by a streoplasmic deposit filling up all the interspaces between the septa and forming the so-called "Gebrämering" of Wedekind; both theca and stereoplasmic deposit

*) One of the coral-studies carried out with a research fund from the Imperial Academy.

1) H. Yabe and M. Eguchi: On a Limestone with Favosites from Erh-tao-kou, West of Kiturin, Manchuria (Preliminary Report).

2) 二道溝.

3) 吉林. 
taken together $1 \mathrm{~mm}$ thick in the stalk-like part, becoming twice or thrice as thick as in calice, and finally thinning out at its periphery. Septa numerous, equal in size, very short, but slightly raised above the stereoplasmic zone; visible on the inner surface of the calice as rather broad radial ridges rounded on their tops, with very narrow

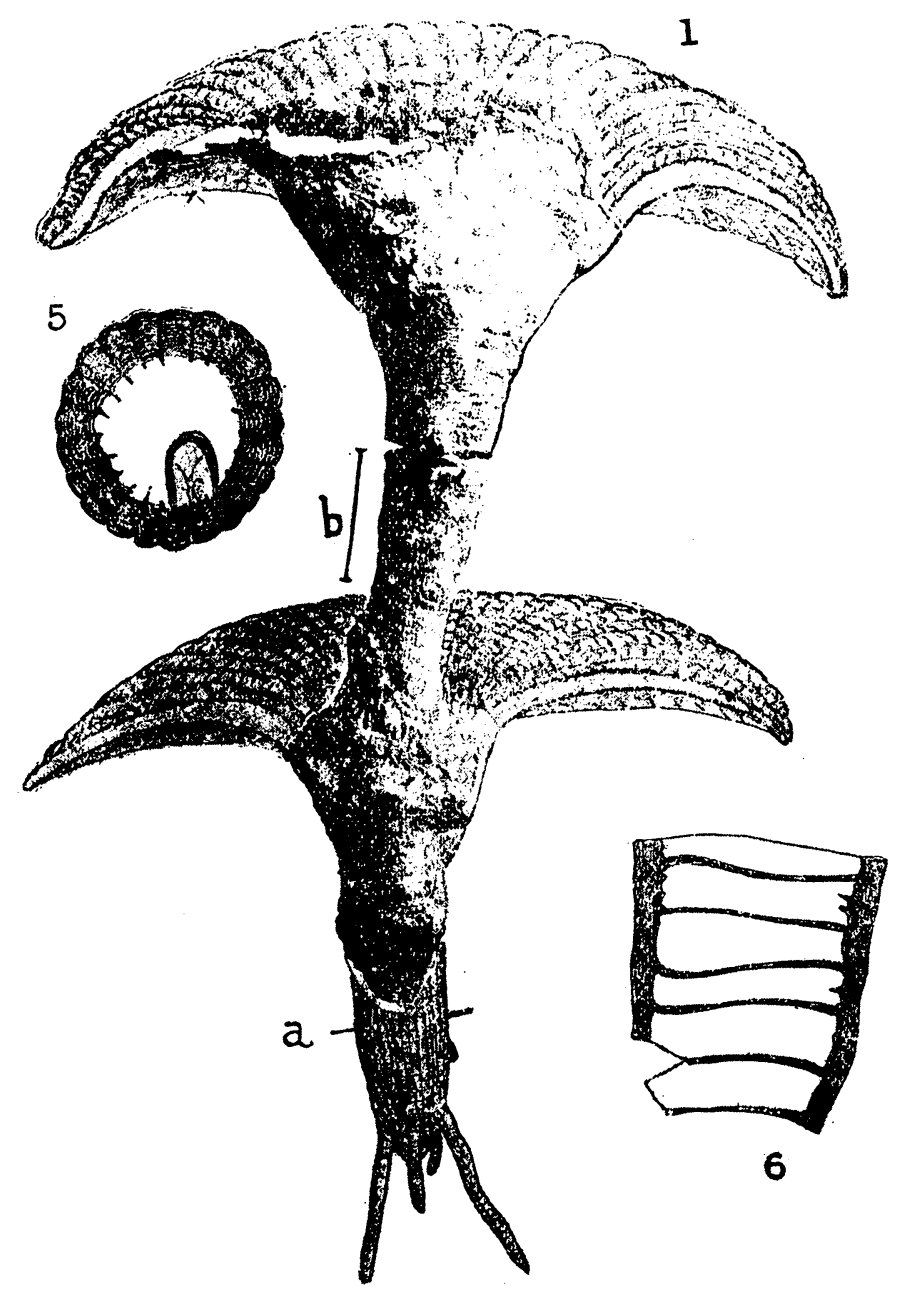

Figs. 1, 5, 6 .

Pseudomphyma infundibula Yabe and Eguchi from the Middle Gotlandian of Erh-tao-kou near Kiturin (explanation in text). 1, x1; $5,6, \times 2,5$

interspaces in between. Tabulae numerous, thin, well-developed, almost horizontal, about 5 in $10 \mathrm{~mm}$; one septum (cardinal ?) in tabular fossula. The most complete of all the specimens we have examined is shown in Fig. 1 ; it is some $120 \mathrm{~mm}$ high, with its calicinal part $90 \mathrm{~mm}$ wide and $25 \mathrm{~mm}$ high, and the stalk-like part $95 \mathrm{~mm}$ high and $10 \mathrm{~mm}$ 
broad in average; it bears a trace of rejuvenation (?) at its middle. All the parts of the corallum which either could not be separated from the matrix, or were broken off in the act of separating it, have been restored.

Fig. 2 represents another specimen which is less complete.

Fig. 3 represents a third specimen consisting only of the calicinal part, preserved in mould.

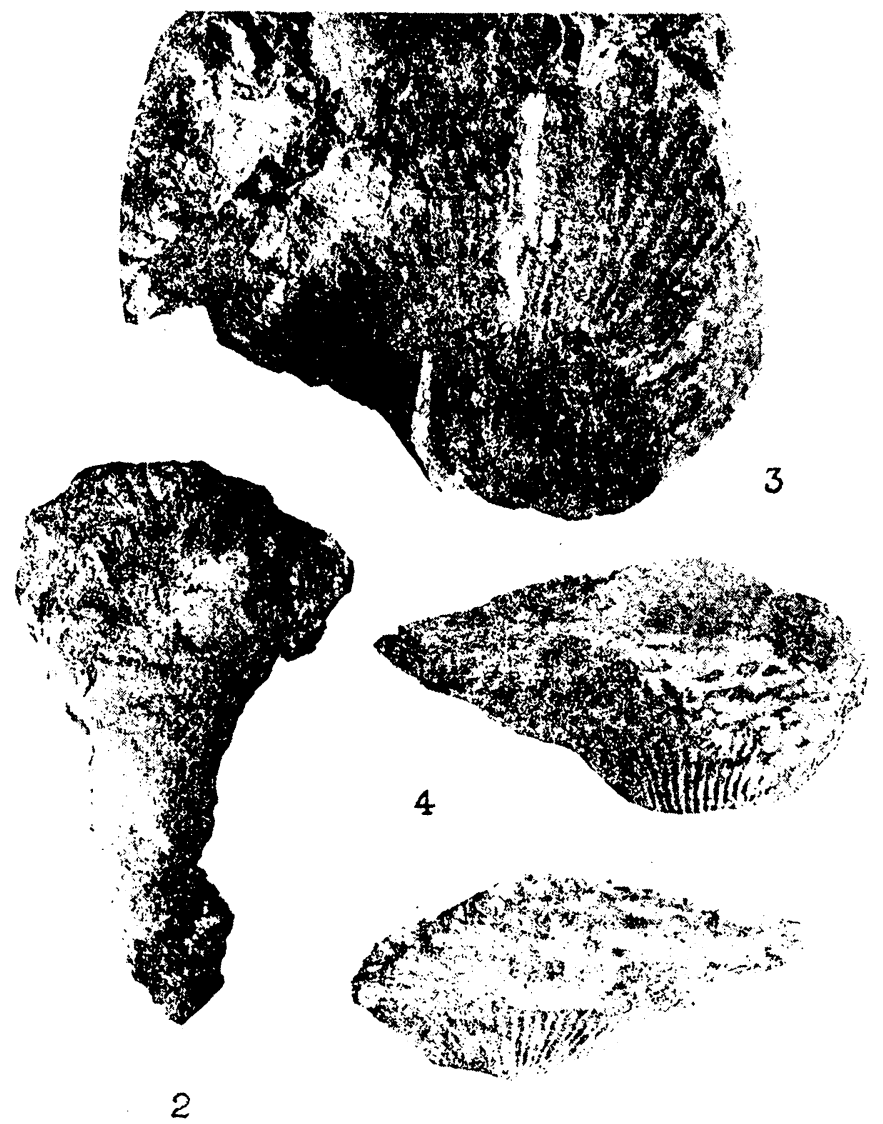

Figs. 2-4.

Pseudomphyma infundibula Yabe and Eguchi from the Middle Gotlandian of Erh-tao-kou near Kiturin (explanation in text). $\times 1$.

Fig. 4 gives two opposite views of a fourth specimen, calicinal part in mould.

Fig. 5. A cross-section of the posterior part, at $a$, of the first specimen. $\times 2.5$.

Fig. 6. A longitudinal section of the posterior part, at $b$, of the first specimen; a number of the septa slightly oblique to the section are visible as spine-like processes on both side. $\times 2.5$. 
Remarks: The present coral agrees precisely with Pseudomphyma in its structural features. This genus, proposed by P.R. Wedekind in his work on the Gotlandian coral faunas of Gotland in the Baltic Sea, 1927'), characterizes the Division IV of Hedströms' Gotlandian stratigraphy of the island, - the Pseudomphyma-stage of Wedekind, which is, according to Wedekind, is the middle division of the Middle Gotlandian in the reef-facies. Corals of this genus, being quite unique in their structure, are of great value as zone-fossils, and there is little or no doubt about the approximate contemporaneity of the Erh-tao-kou limestone to the Pseudomphyma-stage of Gotland. In addition, the reef-nature of the limestone is almost certain, because all the fossils from it we have dealt with, except but one small specimen of Atrypa, are corals.

Wedekind distinguished seven species and one variety of Pseudomphyma in his Gotland material, namely: $P$. atava, $P$. atava var. expansa, $P$. elongata, $P$. profunda, $P$. turbinata. $P$. patella, $P$. murchisoni and $P$. sedgwicki, which are all new.

Among the Gotlandian corals once collected by Yabe from Gotland and now stored in the Museum of the Institute of Geology and Palaeontology, Tohoku Imperial University, there is a fairly good specimen of Pseudomphyma which coincides almost exactly with the description and figures given by Wedekind of $P$. turbinata; the direct comparison of it with the Erh-tao-kou coral afforded further confirmation as to their generic identity.

Specifically, however, the present coral from Erh-tao-kou is easily distinguishable from those species from Gotland dealt with by Wedekind for its long, slender tabulate portion and horizontally expanded, very wide calice with reflexed periphery.

Gotlandian deposits are more or less widely distributed in South China, and some of the limestones are coralline. Wedekind had already taken notice of the alliance of Ptychophyllum cyatheiforme Lindström from the Chaotien district, Szechuan ${ }^{2}$, to Pseudomphyma; this coral represents, he states, an intermediate form between Pseudomphyma and Pilophyllum, possessing convex tabulae and long septa. By these two features, Lindstrom's species differs also from the present coral.

Locality : Erh-tao-kou, $15 \mathrm{~km}$ west of Kiturin, Manchoukuo. Reg. No. 65097 (Institute of Geology and Palaeontology, Tôhoku Imperial University).

Geological age: Middle Gotlandian; probably its middle stage.

1) P.R. Wedekind: Die Zoantharia Rugosa von Gotland (Bes. Nordgotland), nebst Bemerkungen zur Biostratigraphie des Gotlandium. Sverig. Geol. Undersök, Avhandl., Ser. Ca, No. 10, 1927).

2) G. Lindström: Obersilurische Korallen von Tshau-tien im nord-östlichen Theil der Provinz Sz'-tshẁan. Ferd. v. Richthofen's China, Bd. III, 1883, s. 97, Taf. VI, Fig. 9; Taf. VII, Figs. 1, 6, 7. 四川省朝天. 